\title{
Diffuse Proliferation of Pulmonary Neuroendocrine Cells Present
}

National Cancer Institute

\section{Source}

National Cancer Institute. Diffuse Proliferation of Pulmonary Neuroendocrine Cells

Present. NCI Thesaurus. Code C142178.

A morphologic finding indicating the presence of a diffuse proliferation of neuroendocrine cells in the lung parenchyma. 